\title{
“TERRIBLE, BEAUTIFUL DAYS": THE SEMIFICTIONAL WHITMAN
}

Nick MASON-BROWNE

WALT WHITMAN's RELATIONSHIP to fiction is a problematic one. ${ }^{1}$ We generally think of him as a poet, though of course he wrote a great deal of nonfiction, including an autobiography and thousands of newspaper articles, and he certainly tried his hand at fiction. Over a span of ten years (1841-1851), Whitman published some twenty short stories. It is no secret that he was less than proud of these youthful productions, recalling "days when I was writing stories to fill in corners, gaps, in the magazines - stories of no importance to anybody but me, and of no importance to me, but for the fact that they supplied me with necessaries-grub, a living." 2 Commentators such as Thomas Brasher have tended to concur, sometimes bluntly, with this assessment. ${ }^{3}$ But it should not be forgotten that a number of Whitman's stories (e.g., "Death in the School-Room," a ham-fisted tale about the effects of corporal punishment) were quite popular-much more so than the verse he was publishing during the same period-and it is probably fair to say that, at that particular juncture in his literary career, Whitman would have been known, if anything, as the author of the temperance novel, Franklin Evans (1842), and of various works of short fiction. This drab backdrop to a luminous performance in the first edition of Leaves of Grass (1855) is often, and understandably, overlooked, but in fact it has a certain importance, showing as it does that Whitman had acquired a solid, practical grounding in the most rudimentary conventions of fiction, and that he was in a position to apply such knowledge to his experiments with free verse. One of his early notebook jottings that seems to outline Leaves indicates that Whitman was unsure of what form the work would take: "Novel?," he writes, "Play? . . . Plot for a Poem or other work."4

Recent work by critics like Michael Warner and Michael Moon has given renewed attention to Whitman's early fiction, finding therein the seeds of his later concerns, especially his homoeroticism. ${ }^{5}$ Vivian Pollak, in The Erotic Whitman, devotes a chapter to "Why Whitman Gave Up Fiction," arguing that Whitman "stopped writing fiction when the conflict between his desire to uphold the heterosexual values of middleclass family life and his desire to undermine those values in print could 
no longer be ignored." ${ }^{6}$ Whatever his reason for giving up fiction (and Pollak demonstrates it was never a clear-cut decision, since as late as 1859 he was still talking about writing stories) (55), Whitman gradually lost interest in it. Horace Traubel quotes him in 1888 as saying that "[the] short story writers do not as a rule attract me. . . . What do you make of them?-What is their future significance? Have they any? . . . They do not deal in elements: they deal only in pieces of things, in fragments broken off, in detached episodes." "Still, it is important always to keep in mind Whitman's background as both a reader and writer of fiction, because, as a mature poet, Whitman would draw exhaustively on the fullest possible range of sources to be found in the prose discourse of the day-a spectrum which encompassed the rhetoric and formative structures of popular narrative. There is, after all, as much compelling narration in Leaves of Grass as anything else.

While recent investigations into Whitman's fiction have yielded some illuminating results, I want to move in a different direction here and investigate Whitman in fiction, and, more specifically, fictional or semifictional Whitmans. Ed Folsom has investigated at some length the way poets from Whitman's time to the present "talk back" to Whitman and invoke him as a presence in their own poems in order to carry on a conversation with him. ${ }^{8}$ Fiction writers have also responded to Whitman from his own time to our own, creating a broad continuum of works (not all of them short) using fictional devices to a greater or lesser degree in their depiction of Walt Whitman. On the one hand, we can point to The Magnificent Idler (1926) by Cameron Rogers, a book that vividly and sympathetically dramatizes the poet's life, especially his dayto-day subjective progress, and fills in some factual gaps in the historical record. ${ }^{9}$ But what The Magnificent Idler entails, in the end, is merely a kind of generous and enhanced biographical treatment; it does not have, and does not pretend to have, the imaginative heft or reach of fiction. On the other hand, The Start of the Road (1938), by John Erskine, goes a full and audacious step beyond this. ${ }^{10}$ An actual novel-although based, by and large, on then-reputable biographical information-it enlarges on the rumor that in 1848 Whitman had a romantic liaison in New Orleans, making of the presumed relationship a crucial impetus in Whitman's personal and literary development. In this highly fanciful version of the poet's life, Whitman falls in love with a Creole francophone of mixed racial antecedents and has a son by her; it is a direct and explicit consequence of the relationship that he is inspired to write the kind of poetry that will figure subsequently in Leaves of Grass. Indeed, the internal logic of Whitman's entire life experience, as that logic was (and is) conventionally understood, is radically restructured in The Start of the Road so that it conveys a theme of interracial passion (heterosexual) hindered by social norms. 
There is also a novel by Elizabeth Corbett called Walt: The Good Gray Poet Speaks For Himself (1928), which falls somewhere in the gap between these two works. ${ }^{11}$ Conversations from, or relating to, the poet's life are vividly recreated in the book, usually by means of embellishment or outright invention. The novel is configured, in fact, as a sequence of fifty-one dialogues (called chapters), each one preceded by the equivalent of stage directions; and the overall effect is rather like that of a script for a radio play or a motion picture. Even today, Walt has, from a purely technical standpoint, something of an edgy quality, deserving comparison, perhaps, with the "dialogue novels" of Ivy ComptonBurnett. Yet the cumulative story it tells scarcely departs at all from the narrow biographical track blazed by Cameron Rogers. Like Erskine, Corbett does, however, follow the speculative line that Whitman fathered a child in antebellum Louisiana.

Looking elsewhere, we discover fictional works such as Edith Wharton's The Spark (1924)..$^{12}$ Such works make use of the historical Whitman as a mere point of departure; the poet is absent, yet he suffuses the narrative as an intangible, transformative influence on someone. An extreme, and perhaps marginal, example of this special permutation is "Old Doc Rivers" (1932), a story by William Carlos Williams. ${ }^{13}$ In "Old Doc Rivers," it has been suggested, Whitman lies embedded within the title character, a faint representation of Williams's ambivalence about Whitman as a literary influence, and is accessible only through elaborate critical exegesis. One might well ask whether Whitman is, in fact, liable to be present, implicitly or otherwise, in such a straightforward and anecdotal narrative, based on the character and circumstances of an actual physician and so conducive to a discussion of purely medical issues. But the interpretation is both intriguing and cleverly defended, and it cannot be entirely discounted. ${ }^{14}$

At the opposite end of the spectrum are a number of highly elaborate and fanciful concoctions, explicit to precisely the degree that The Spark is not, in which Whitman seems to have evolved, or be evolving, into someone else altogether-a kind of hyperbiographical personage, part god and part caricature, more virtual than actual, subject to the conventions of science fiction and the neo-Gothic imagination. In Paul Di Filippo's "Walt and Emily" (1995), for instance, Whitman participates with Emily Dickinson in a spiritualist-scientific expedition to the hereafter and encounters the future departed shade of Allen Ginsberg. ${ }^{15}$ In Peter Doyle (1991), a novel by John Vernon, the historical relationship between Whitman and the young Confederate veteran, Peter Doyle, richly imagined and given full emotional resonance, meshes with a Byzantine plot involving (among other things) a macabre collectible (Napoleon's mummified penis); a malevolent, artificially-created ho- 
munculus; Horace Greeley's vision of utopia; and (again) a fictive juxtaposition of Whitman and Emily Dickinson. ${ }^{16}$

While its prose style and plot devices seem unprepossessing, even lame, in comparison with those of such elaborate fictions, The Day I Met Walt Whitman (2001) by Gregory Leifel may actually trump them in its depiction of Walt Whitman as an unearthly spiritual advisor who materializes to assist a terminally ill man (named Gregory Leifel) in the reappraisal of his life. ${ }^{17}$ Neither futuristic nor neo-Gothic, the novel incorporates a loose amalgam of the conventions of the novel, the spiritual autobiography, and the self-help manual. On this basis, it manages to establish its own diminutive, quirky niche; and the sincerity of the sentiments it expresses, together with its modest, but striking, narrative premise, can win over even the most jaded or skeptical reader. The Day I Met Walt Whitman appears to make a highly persuasive case for Whitman, not in the end as a writer at all (notwithstanding a generous provision of quotations from Leaves of Grass), or even as a nineteenthcentury American, but as an entirely new personage who manages to be both ahistorical and placidly infallible - a cross between a guardian angel and a supernatural guru.

As an excellent new anthology has demonstrated, there is also a considerable body of poetry concerned with Whitman and his life, at times making use of the same basic enablements (e.g., letters to and from the poet) and often showing the same preoccupation with the traumatic effect of sectional warfare as the prose works I have described. ${ }^{18}$ The fact is that a diverse array of lyrical texts, some historically accurate and some not, some of a markedly narrative cast, falls somewhere within the reach of this survey. I would venture further and argue that even the celebrated photographic portraits of Whitman, together with other painted and sculptural likenesses, as implicit narratives about a range of public postures and roles, have a place in the discussion. The "stories" that such works, both literary and graphic (or plastic), tell about Walt Whitman may seem disparate; but the kind of variegation which they embody coincides, quite simply, with the diverse range of perceptions which readers and enthusiasts might well have had, and can still in fact have, of the Good Gray Poet. Even today, there are, of course, votaries who think of Whitman as a prophet of world peace, an exemplar of the proletariat, a gay patriarch, or an incarnation of cosmic love. Such convictions, authentic and often deeply felt, are characteristically underwritten and powerfully reaffirmed by the poet's literary accomplishments, but it is Whitman himself, as a literary projection and an icon or cult figure, who is the actual focus of veneration. That is, indeed, exactly how William James, a century ago, made sense of Whitman-as a striking, univocal presence emblematic of a distilled and simplified idea, rather than a complex, historical individual or the embodiment of a 
variable, and even inconsistent, textual practice. And the fact that an academic philosopher could do this as part of a lengthy, measured formal commentary merely underscores the strength and pervasiveness of the larger tendency that was, and continues to be, operative.

Let's begin, then, by examining William James's creation of a familiar Whitman. Whitman, of course, was accorded a significant place in the famous series of lectures given by James at the University of Edinburgh in 1901 and 1902. In those lectures, subsequently published as The Varieties of Religious Experience (1902), James pointed repeatedly to Whitman as the perfect embodiment of a certain religious philosophy. Whitman, he said, was "the supreme contemporary example of [the] inability to [acknowledge or accept] evil" and of a "religion of healthy-mindedness" (182). Such a religion was, he found, deeply unsettling and, in the last analysis, unacceptable. During the course of the lectures, James returned to the subject on several occasions, arguing that Whitman's "natural" or "pagan" philosophy was "inadequate" because "the evil facts which it refuses positively to account for are a genuine portion of reality; and they may after all be the best key to life's significance. . . ."19 In 1903, in the course of delivering a speech about Emerson's character and legacy, James went so far as to distinguish clearly between Emerson's authentic "optimism" and Whitman's "indiscriminate hurrahing for the Universe. . . ." Such opinions hearkened back to an earlier (1895) lecture, "Is Life Worth Living?", in which it was suggested, along the same lines, that "many men" possess "a temperamental optimism which makes them incapable of believing that anything seriously evil can exist. Our dear old Walt Whitman's works are the standing text-book of this kind of optimism." 21 And in James's correspondence, we find sporadic and off-hand references to Whitman which are often quite revealing and even show a measure of Jamesian ambivalence. For example, in a letter to his wife, James writes: "I am sorry to hear that Louise is so un-Walt Whitman like in her powers of enjoying whatever comes along." 22 Writing in June of 1887, James observes to Mr. Blood: "Your letter does one's very heart good. I am so delighted to find that a metaphysician can be anything else than a spavined, dyspeptic individual fit for no other use. Most of them have been invalids. I am one, can't sleep, can't use my eyes, can't make a decision, can't buy a horse, can't do anything that befits a man. . . . You seem to be a man after Walt Whitman's own heart-I've got much good from that man's verse, - if such it can be called" (Correspondence 6:234).

Based as it largely was on the quasi-hagiographic depiction of Whitman by R.M. Bucke (in Cosmic Consciousness), the version of Whitman discussed by William James was, it is fair to say, not so much the man himself as a semifictional construct similar to the self envisioned and projected by "Song of Myself"- one of several such alter 
egos which the poet created (or allowed others to create) during a long and much-publicized career. As it happens, it is precisely this same semblance of Whitman which has figured sporadically as a character in works of American short fiction such as "The Carpenter" (1868) by William Douglas O'Connor, "Pages from a Wound Dresser's Diary" (1979) by Richard Selzer, "Reassurance" (1990) by Alan Gurganus, "Ancestors" (1991) by Fred Chappell, and "Every Night for a Thousand Years" (1997) by Chris Adrian. And it is precisely the crucial difficulty contemplated by William James in his lectures that at bottom galvanizes all five of these stories, which I would now like to examine in some detail.

Set against the backdrop of the early 1860 s-those "terrible, beautiful days" (Traubel 1:115) when the author (and protagonist) of Leaves of Grass, while working as a hospital missionary, struggled to come to terms with "the evil facts" of war - these five narratives, stylistically dissimilar, place Whitman's moment of personal crisis in a range of distinct perspectives. Yet they seem, at bottom, remarkably alike-complementary works, establishing an odd little subgeneric category all their own. Whatever philosophical standing James's evaluation of Whitman might have-and the short fiction which concerns us comes effectively to grips with that evaluation -it really points to something else: the complicated relationship which can exist between poet, poetic subject, and a reader whose "text" may be some version of the poetic subject and have a loose or problematical relation to the poet himself and his writings. By courting a special kind of celebrity, chimerical in its appeal to political, religious, and even sexual enthusiasms, Whitman himself cleared the way for such complications to arise.

It should come as no surprise, then, that the fictional works examined here deal so obliquely, for the most part, with the poems of Leaves or, for that matter, with poetry itself. Over a span of time, the largerthan-life protagonist of "Song of Myself," as much a fictional extrapolation as anything else, has acquired a multifaceted life of his own, one existing at a distinct and widening remove from Whitman's writings. Implicitly, the various semifictional and fictional works depicting Whitman serve to remind us that this is so, and they point to the figural and dramatic potentialities proper to the relations between poet and poetic subject. Such potentialities are more fully and consciously exploited elsewhere-in the ingenious use of the heteronym (alter ego) by the Portuguese modernist, Fernando Pessoa, for example - but it is fair to say that they were already latent in the first edition of Leaves of Grass and have found curious, displaced expression in the various fictional portrayals of that book's author.

How central or crucial, then, are semifictional representations of Walt Whitman to an actual understanding of Whitman himself or of what he wrote? I would argue that they are more germane than is at first 
apparent. Jorge Luis Borges, in one of his brief essays, may well have put his finger on it when he says that "there are two Whitmans: the 'friendly and eloquent savage' of Leaves of Grass and the poor writer who invented him." 23 By "poor," of course, Borges means sadly pedestrian-a poet who sang the praises of California as if from personal experience but never actually went there, and whose amorous adventures in print were, perhaps, somewhat fanciful. In advancing such a view, Borges draws, of course, on the more formal and methodical assessment of Henry Seidel Canby. In his biography of Whitman, Canby argued that there was a "theatrical sense of identity in Whitman"24 and that "the ego of the poems was a dramatized symbol" (125). Canby felt that "probably in [Whitman's] life, certainly in his poetry, there is no sharp boundary between phantasy and reality" (197). The America of Leaves of Grass was thus "not a real America. . . . It was a symbolic America, existing in his own mind" (v); and Canby stated flatly that there are "no truly objective love poems in the "Leaves of Grass" (205). From Canby's point of view, Whitman's Civil War experience was of critical importance, compelling the poet to confront harsh realities, but ultimately beneficial to him. "There is more realism," he suggests, "in one of Whitman's letters to his mother from the Washington hospitals than in all his 'Leaves"' (340). But the traumatic shocks of the Civil War made it possible for Whitman's vision of democratic America to become grounded in an authentic and substantive appreciation of the so-called en-masse, of the ordinary Americans he had previously observed, but not confronted in intimate or significant contexts. In later life, according to Canby, Whitman went so far, in an unguarded moment, as to concede as much himself (65).

The fact of the matter is that Walter Whitman, Jr., both as a literary lion and a lyrical protagonist, was completely immersed in the business of semifictional representations. Such versions of Whitman as appear in the stories we are considering are, on some fundamental level, structurally analogous to the projections of Walt Whitman himself. William James may well have reflected on such considerations, but in the end he was prepared to take the "philosophy" of Leaves of Grass at face value-as something embodied and lived and realized, as a closed set of values, rather than something simply yearned for and imagined, something openended and potential, as much virtual as actual. Borges has precisely this wrong-headed response to Whitman in mind when he argues that "the mere happy vagabond proposed by the verses of Leaves of Grass would have been incapable of writing them" (72). We know that James drew a basic distinction between an "empirical self or me," which encompassed the social interactions and public reputation of the individual, and a more central and private "spiritual me." 25 Did it not occur to him that Whitman had experimented ingeniously and daringly with such selves, 
transforming the spiritual self into an empirical one, and vice versa? In this perspective, Whitman emerges as a more sophisticated, percipient and complex participant in, and observer of, life than James gave him credit for.

At this point, we turn to our examples of short fiction. The first of these, "Every Night For a Thousand Years" by Chris Adrian, appeared originally in The New Yorker. ${ }^{26}$ It is a conventional, third-person narrative, based on a letter which Whitman wrote on August 10, 1863, to the parents of one Erastus Haskell. ${ }^{27}$ Haskell was a soldier in the 141st New York Volunteers who died in the Armory Square Hospital in Washington, D.C. The text of Whitman's letter is skillfully incorporated, with some minor alterations, into the story. Erastus Haskell becomes Hank Smith, a young patient who cannot bear the thought of his leg being amputated, and whose circumstances deeply affect his special benefactor and confidante-the "hospital consolator," Walt Whitman. Since its publication, the story has been absorbed into the larger currents of a remarkable novel called Gob's Grief (2000), and it is instructive to examine the subtle alteration it has undergone in that process. ${ }^{28}$ Whereas the original story had a clipped, muted quality, the corresponding section of the novel has been tweaked to amplify certain emotions. A new character is introduced: a patient in the hospital who actively dislikes Whitman to the point of striking him when the poet is distraught after Hank Smith's death. That patient's raw hostility is the note on which the section concludes. On the other hand, a new incident is also devised, in which a boisterous Whitman allows himself to be pushed about in a wheelbarrow by two small girls. This vignette brings out a childlike and ebullient dimension of Whitman's character that the original story only hinted at. On this basis, the essential theme of the narrative emerges with singular clarity. In Adrian's story, Whitman is the embodiment of a pure and innocent tenderness, a tenderness brought low by gruesome realities. A single quote will suffice to convey the basic tenor of the story: Hank - the narrator tells us-"fell on the Mall, and the crutch broke under him. He wept softly with his mouth in the grass. Walt picked him and carried him on his back, toward the canal and over it, then into Murder Bay. Hank cried to be put down. They rested on a trash heap teeming with small crawly things that were unidentifiable in the dark" (102).

The original short story, packed with vivid details about Civil Warera medicine (at the time he wrote the story, Adrian was a medical student in Virginia) and suffused throughout with a kind of glimmering melancholy, is highly accomplished and affecting. If the semifictional Whitman of the story confronts the stark realities of the Civil War and feels broken and overwhelmed, that has, of course, some basis in fact. "Mother," Whitman wrote in a letter dated June 7, 1864, "it is most too 
much for a fellow, and I sometimes wish I was out of it." 29 But one recalls that despair was not the poet's exclusive or definitive response to his wartime experience. In some respects, he was even fascinated by war and sensed that its horrors offered him some inexplicable glimpse into a mystery. In a letter to Emerson, dated January 17, 1863, he was able to write: "The Hospital, I do not find it, the repulsive place of sores and fevers . . . a new world here I find as I would show-a world full of its separate action, play, suggestiveness - surely a medium world, advanced between our well-known practised one of body and of mind, and one there may be somewhere on beyond, we dream of, of the soul." ${ }^{30}$ Both the story and what we know about Whitman's wartime experience point to a darker, and more complex, response on the part of the poet than William James might have anticipated.

The Allan Gurganus story has a great deal in common with "Every Night for a Thousand Years," and yet is fundamentally different. ${ }^{31}$ "Reassurance" is also based on an actual letter by Whitman - this one reporting the death of Frank H. Irwin, Company E, 93rd Pennsylvania, to his parents in May, 1865-and it also quotes the letter verbatim. ${ }^{32}$ It is a two-part polyphonic narrative, with both Whitman himself and the dead soldier taking turns as narrator; but notwithstanding this technical feature, it is a generously simple story. In his characteristically tender and comforting way, Whitman recounts Frank Irwin's last moments, explaining that the surgeon did everything that could have been done under the circumstances, and praising the soldier's exemplary conduct. Then, in a fanciful extrapolation, the dead spirit of Frank Irwin conveys a similar message of sympathy and closure to his mother. The message takes the form of an utterance the mother hears in a dream. It is insinuated that, by a kind of psychological or spiritual magic, the special qualities of Whitman's letter have set the stage for this and made it possible. There is a moment of visionary transcendence at the end of the story, one which seems especially appropriate in a story about Whitman, when Irwin urges his mother to put aside her grief and live fully again. The brightness of ordinary daylight, he tells her, is "something very holy" (Gurganus 231). He pushes her towards the daylight and exhorts her to wake. As this synopsis makes plain, "Reassurance" has its own distinctive take on Whitman's Civil War experience. Here the personal philosophy of which William James disapproved so strongly comes gently and firmly to grips with the "evil facts" of war and transcends them. The story's genial optimism is an almost perfect foil to the controlling point of view in "Every Night for a Thousand Years."

Of the various portraits of Whitman which we are considering, the most striking is the one delineated in "The Carpenter" by William Douglas O'Connor. ${ }^{33}$ This story was first published in Putnam's Magazine in 1868 and was pitched to the expectations of a Victorian readership. It 
therefore has all the appurtenances and ponderous machinery of nineteenth-century narrative. There is an elaborate, slow-moving plot. The prose is heavily larded with descriptive passages, moral commentary, rhetorical flourishes, classical allusions and bursts of lyric sentiment. The story's ornate diction embraces not only learned usages, but a stock of vivid American slang - "Jillery poo!"; "flambustuous"; "By the grand gorrifications!" - and so forth. Such stylistic traits will not, in all likelihood, endear "The Carpenter" to the postmodern reader; and yet it is a pleasure to read, and in its own way a tour de force.

The story's plot entails an itinerant incarnation of the Messiah who, on Christmas Eve, 1864, visits a farmhouse and intervenes dramatically, not to say miraculously, in the life of a family with divided sectional loyalties. The family is under the mistaken impression that their guest is a Mr. Carpenter, but it is plain to the reader, virtually from the outset, that, in fact, the miracle-worker is Mr. Walt Whitman. There is an extraordinary sense of manifest religious sentiment, of something approaching rapture, which pervades this narrative of a Second Coming and impels it towards an emotional crescendo. The story is perhaps analyzed to best advantage from the standpoint of propaganda-in particular, those archaic forms of propaganda that once served the spread of Christianity. The plot-line of "The Carpenter" bears a faint, but uncanny, resemblance to conventional plot-lines in Hellenistic romances about traveling miracle-workers-plot-lines which were skillfully absorbed into the apocryphal Acts. ${ }^{34}$ The compendium of medieval biographies of proselytizers and saints is merely an extrapolation of this and other conventions established in antiquity. After his own fashion, a deeply religious man, as well as an expert polemicist, O'Connor must have intuitively understood, and perhaps fallen back on, the age-old devices of Judaeo-Christian apologetics.

Given this basis, it is hardly surprising that "The Carpenter" comes close to being a univocal text: it is controlling, even coercive; it enjoins us to imagine a Walt Whitman who is as much an ideological emblem or votary figure as a fictional semblance of a person; with the best of intentions, it conscripts and regiments every nuance of our emotional response. This particular variant on Whitman is not only undaunted by the Civil War, not only able to heal its rifts with his Christ-like presence and actions, but has, into the bargain, a stern homily for almost everyone within earshot. $\mathrm{He}$ is at the furthest possible remove from the Whitman of "Every Night For a Thousand Years," and almost certainly from the historical individual himself - the gentle, middle-aged man who gave out oranges and stationery to patients in the military hospitals of Washington, D.C. This is a Whitman who would brook no criticism from the likes of Professor James; he transcends discussion. 
In fairness to William James, it must be emphasized that his thinking was capacious enough, and generous enough, to accommodate contradictory vantage points; he was quite capable of approaching the ideas of someone like Whitman from more than one angle, and of at once disparaging and esteeming such ideas on that plural basis. As a recent essay on the subject has made clear, James was, for example, able to sense and appreciate an essential, underlying compatibility of Whitman's views with the opinions which James had invested in the philosophy of pragmatism..$^{35}$ On a deeper and more fundamental level, the inclusive character of James's habits of rumination was itself compatible with the multivocal, open-ended complexity of Whitman's best poetry. But of course neither of these tendencies is evinced in the robust certainties of "The Carpenter" or in the drastic simplification which informs James's quarrel with Whitman's "indiscriminate hurrahing."

For its part, "Ancestors" (1991), a story by the Southern writer, Fred Chappell, makes liberal use of the conventions of science fiction and the ghost story; however, it is, more properly, a regional tall tale of the sort that Samuel Clemens or Stephen Leacock would have relished. ${ }^{36}$ As such, it encompasses a cozily droll spoof of Southern foibles and, in particular, the veneration of Civil War connections and antecedents. The story's premise is that the artificial ghosts (computer-generated simulations) of several Civil War ancestors are deposited, one after the other, on the doorstep of a suburban couple. All of these visitors, it develops, are appalling house guests, but the last of them-Wade Wordmore, a comic version of Walt Whitman - is perhaps the most insufferable of the lot. An indefatigable and feckless windbag, Wordmore converses as if constantly in the process of rewriting Leaves of Grass: "Gladly I go where I am wanted and unwanted. . . . The world is my home, in it I am free to loaf and meditate, every particle is as interesting to me as every other particle, the faces of women and men gladden me as I journey. . . . I, Wade Wordmore, American, untrammeled by boundaries, unfixed as to station, and at my ease in climes and latitudes, answer to no laws save those of my perfect nature (for I know that I am perfect, how can a man tall and in pure health be not perfect?)."

On the one hand, Wordmore is a benign, radiant presence-so much so that he seems to produce "an almost visible emanation of peaceful healthful ease" (24), and there is speculation that he might have served in some medical capacity during the Late Unpleasantness. But he also suffers from an especially irritating form of verbal diarrhea, and there is something fatuously upbeat about his wide-ranging pronouncements, as if he were simply oblivious to any hindrance or contrary fact. As the story draws to a close, it becomes evident that countless duplications of ancestors, both Federal and Confederate, have been produced, and that a second Civil War is in the offing, but the Whitman-Wordmore 
simulacrum scarcely pauses to draw breath: "the beautiful young men falling in battle amid smoke of cannon and the sky louring over the mothers weeping at the night and the sweethearts weeping" (26). As occurred in Gob's Grief, the Whitman character is, in the end, sharply rebuked, but, on this occasion, the reader is liable to feel more relief than sympathy.

In the simplest structural terms, "Ancestors" involves a juxtaposition of a sanitized, suburban nostalgia for the Civil War and the harsh realities of that conflict. The inclusion of Whitman complicates this arrangement by proposing a contrast between Whitman's quixotic, transcendentalist vision and the inimical realities it distorts or ignores. The Walt Whitman of the story is, needless to say, a mere caricature, a hyperbolic gesture. But caricatures have a way of coalescing around some tiny particle of truth, even if that truth involves a durable misperception of a famous poet. It is here, perhaps, that Walt Whitman, as a fictional construct, and William James's notion of what Whitman was, most nearly coincide. Pricking as it does the bubble of sanctity that sometimes surrounds the author of Leaves of Grass, "Ancestors" serves as a highly effective retort to "The Carpenter." What it does not accomplish, and cannot even attempt without contradicting its own constitutive basis, is to provide a rounded or nuanced account of Whitman's Civil War.

In a sense, the same caveat applies to the other stories scrutinized thus far. Their versions of Whitman are one-dimensional, and their thematic scope seems correspondingly narrow. Is it possible, in fact, for a short story to apprehend the full breadth and depth of Whitman's response to what he saw and heard in the 1860s? A piece entitled "Pages from a Wound Dresser's Diary," by Richard Selzer (a physician), appears to manage this difficult feat, although it does so on its own unorthodox terms. ${ }^{37}$ The story is narrated by a version of Whitman called William. He is serving as a military surgeon on steamboats plying southern rivers. William is an amalgam, in point of fact, of Whitman and an actual surgeon named Lauderdale, on whose letters the narrative is largely based. ${ }^{38}$ The language of the story is authentically poetic, making use of striking and original figures of speech, yet making no effort at all to emulate Whitman's own stylistic habits. And the narrator's response to his experience is not really a unitary response at all, but rather a panoply of reactions which are difficult to sort out. He is, by turns, horrified, grief-stricken, numb, bored, callous, and overwhelmingly fascinated by everything he sees; and he is ultimately exhilarated in some way that perhaps no philosophical program (Jamesian or otherwise) could adequately describe. There is an almost tactile sense of intimacy, of being close to Whitman himself; and we instinctively grasp why the poet, reminiscing in old age about his Civil War experience, might have referred to that time as those "terrible, beautiful days." Whitman himself com- 
plained that the War would never be properly chronicled, but one elusive dimension of it, the one closest to him - that of a poetic sensibility exposed to the harshest exigencies - has been divined in "Pages from a Wound Dresser's Diary." Beyond easy characterization or categorization-just like Whitman's best work-Selzer's story is a remarkable narrative experiment.

In the notebook I mentioned earlier in this essay, where Whitman imagines the persona of Leaves of Grass but still is unsure whether the work will be a novel or play or poem, he tries to describe the fluid and multivalent character that he would eventually create in his poetry: "Nobody appears upon the stage simply-but all in huge aggregates nobody speaks alone-whatever is said, is said by an immense number ... A manly unpretensive philosopher-without any of the old insignia, such as age, books etc. . . . To him for advice come all sorts of people.Some come to puzzle him" ( $D B N$ 3:774-775). The challenge for fiction writers who have sought to portray Whitman has always been to come up with a character similarly huge and puzzling, an aggregate, someone beyond the delimiting iconographic Whitman that the poet himself often encouraged. Few have accomplished it, but the fictional search for Whitman is far from over.

\section{Coe College}

\section{NOTES}

1 Several Whitman scholars made helpful comments about an early draft of this paper. The present text benefits, in particular, from modifications suggested by Ed Folsom, Kenneth Price, and M. Jimmie Killingsworth. I owe a special debt to Ed Folsom for his guidance and encouragement.

2 Horace Traubel, With Walt Whitman in Camden, ed. Jeanne Chapman and Robert MacIsaac (Oregon House, California: William Bentley, 1996), 8:410.

3 See his comments in Walt Whitman, The Early Poems and the Fiction, ed. Thomas

L. Brasher (New York: New York University Press, 1963), xvii.

4 Walt Whitman, Daybooks and Notebooks, ed. William White (New York: New York University Press, 1978), 3:774-775.

5 See Michael Warner, "Whitman Drunk," in his Publics and Counterpublics (New York: Zone Books, 2002), 269-289; and Michael Moon, Disseminating Whitman, especially Chapter 1, "Rendering the Text and the Body Fluid: The Cases of 'The Child's Champion' and the 1855 Leaves of Grass," 26-58. Warner reads Franklin Evans as Whitman's early struggle with addiction, self-mastery, and "voluntarist culture," and he argues that it was the "contemplative, expressive side of individualism" that "Whitman in the 1850s radicalized out of the dialectic visible in the 1842 novel." Moon sees several themes in "The Child's Champion" that get developed in Whitman's poetry, including "an important lesson in the interdependence of transgressive writing and censorship." 
6 Vivian Pollak, The Erotic Whitman (Berkeley: University of California Press, 2000), 54.

7 Horace Traubel, With Walt Whitman in Camden (Boston: Small, Maynard, 1906), $1: 78$.

8 Ed Folsom, "Talking Back to Walt Whitman," in Jim Perlman, Ed Folsom, and Dan Campion, eds., Walt Whitman: The Measure of His Song (Duluth: Holy Cow!, 1998), 21-75.

9 Cameron Rogers, The Magnificent Idler (Garden City, NY: Doubleday, Page, 1926).

10 John Erskine, The Start of the Road (New York: Frederick A. Stokes, 1938).

11 Elizabeth Corbett, Walt: The Good, Gray Poet Speaks For Himself (New York: Frederick A. Stokes, 1928).

12 Edith Wharton, Old New York: The Spark (The 'Sixties) (New York: Appleton, 1924). Kenneth M. Price in To Walt Whitman, America (Chapel Hill: University of North Carolina Press, 2004), deals with The Spark in the context of Wharton's careerlong "constructions of Whitman" (37). Price also deals with Whitman's presence in the work of other fiction writers, like John Dos Passos, Bernard Malamud, Gloria Naylor, and Ishmael Reed, as well as in films from 1913 to the present.

13 William Carlos Williams, "Old Doc Rivers," in The Knife of the Times and Other Stories (Ithaca, New York: The Dragon Press, 1932), 121-164.

14 Daniel Morris, "Old Doc Rivers," in The Writings of William Carlos Williams: Publicity for the Self (Columbia: University of Missouri Press, 1995), 65-73.

15 Paul Di Filippo, "Walt and Emily," in The Steampunk Trilogy (New York: Four Walls Eight Windows, 1995), 237-352.

16 John Vernon, Peter Doyle (New York: Random House, 1991).

17 Gregory Leifel, The Day I Met Walt Whitman (Cary, IL: Thriving Moss Publications, 2001).

18 See Sheila Coghill and Thom Tammaro, eds., Visiting Walt: Poems Inspired by the Life and Work of Walt Whitman (Iowa City: University of Iowa Press, 2003).

19 William James, The Varieties of Religious Experience (New York: Random House, 1994), 96.

20 William James, "Address at the Centenary of Ralph Waldo Emerson (1903)," in Pragmatism and Other Writings (Harmondsworth: Penguin, 2000), 312.

21 William James, "Is Life Worth Living?" in Pragmatism and Other Writings (Harmondsworth: Penguin, 2000), 219.

22 William James, The Correspondence of William fames, ed. Ignas K. Skrupskelis and Elizabeth M. Berkeley (Charlottesville: University Press of Virginia, 1998), 7:524; hereafter Correspondence.

23 Jorge Luis Borges, "Note on Walt Whitman," in Other Inquisitions (1937-1952), trans. Ruth L.C. Simms (New York: Washington Square Press, 1966), 72.

24 Henry Seidel Canby, Walt Whitman: An American (Cambridge, MA: Riverside Press, 1943), 83. 
25 Quoted in Gay Wilson Allen, William fames (Minneapolis: University of Minnesota Press, 1970), 22.

26 Chris Adrian, "Every Night for a Thousand Years," The New Yorker (January 10, 2000), 96-103.

27 Whitman to Mr. and Mrs. S. B. Haskell, August 10, 1863, in The Correspondence, ed. Edwin Haviland Miller (New York: New York University Press, 1961), 1:127130.

28 Chris Adrian, Gob's Grief (New York: Broadway Books, 2000), 25-45.

29 Whitman to Loiusa Van Velsor Whitman, June 7, 1864, in Corr., 1:231.

30 Whitman to Ralph Waldo Emerson, January 17, 1863, in Corr., 1:68-69.

31 Allen Gurganus, "Reassurance," in White People: Stories and Novellas (New York: Ballantine, 1990), 218-231.

32 Whitman to Mrs. Irwin, May 1, 1865, in Corr., 1:258-260.

33 William Douglas O'Connor, “The Carpenter," in Three Tales (Boston and New York: Houghton, Mifflin, 1892), 211-319.

34 See Paul J. Achtemeier, "Jesus and the Disciples as Miracle Workers in the Apocryphal New Testament," in Aspects of Religious Propaganda in Fudaism and Early Christianity, ed. Elisabeth Schussler Fiorenza (Notre Dame: University of Notre Dame Press, 1976), 149-186.

35 See Raphael C. Allison, "Walt Whitman, William James, and Pragmatist Aesthetics," Walt Whitman Quarterly Review 20 (Summer 2002), 19-29.

36 Fred Chappell, "Ancestors," Chronicles: A Magazine of American Culture 15 (March 1991), 17-26.

37 Richard Selzer, "Pages From a Wound Dresser's Diary," in Confessions of a Knife (New York: Simon and Schuster, 1979), 133-148.

38 For confirmation of this, see Robert Leigh Davis, Whitman and the Romance of Medicine (Berkeley: University of California Press), 120-121. 